Provided for non-commercial research and education use. Not for reproduction, distribution or commercial use.

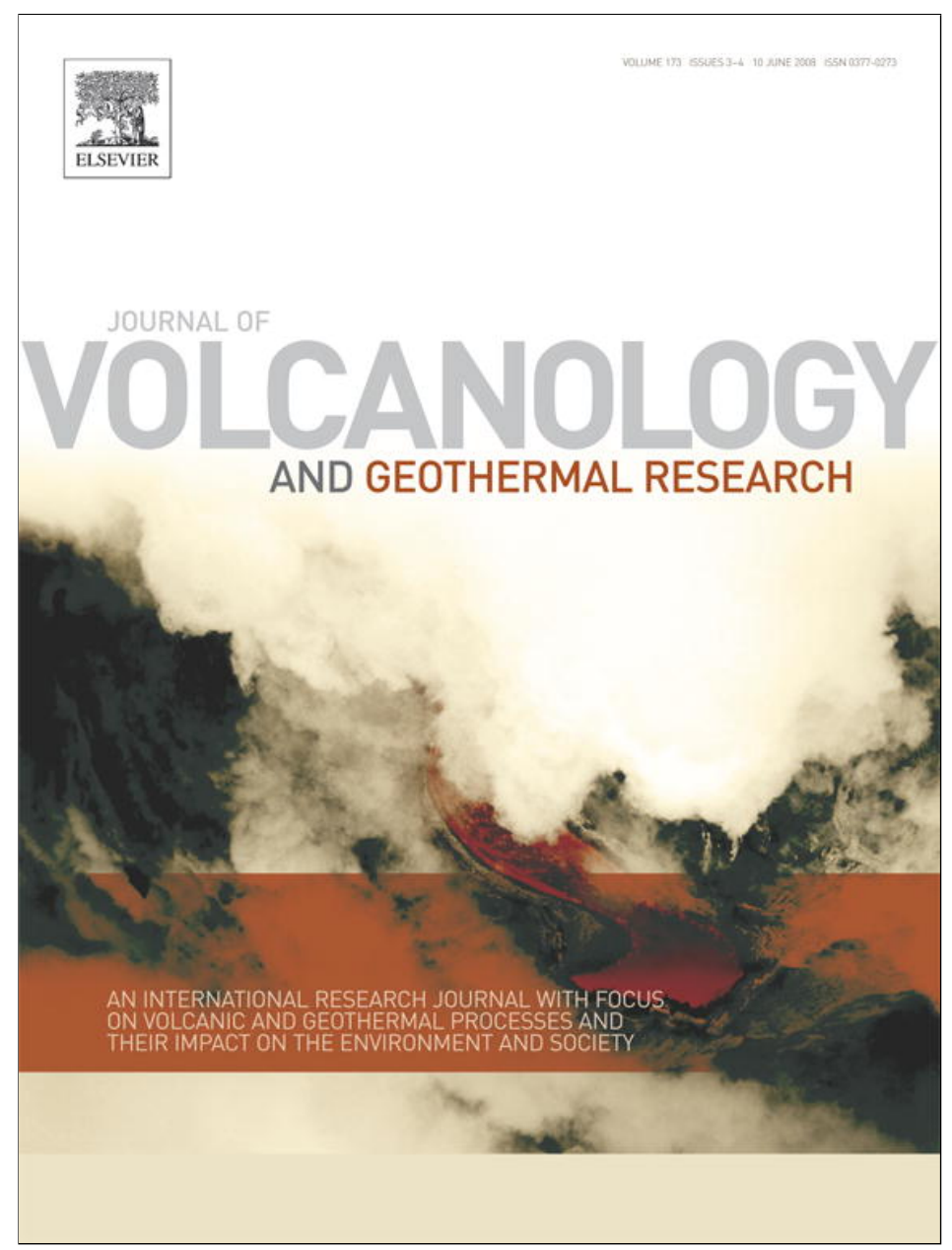

This article appeared in a journal published by Elsevier. The attached copy is furnished to the author for internal non-commercial research and education use, including for instruction at the authors institution and sharing with colleagues.

Other uses, including reproduction and distribution, or selling or licensing copies, or posting to personal, institutional or third party websites are prohibited.

In most cases authors are permitted to post their version of the article (e.g. in Word or Tex form) to their personal website or institutional repository. Authors requiring further information regarding Elsevier's archiving and manuscript policies are encouraged to visit:

http://www.elsevier.com/copyright 


\title{
Satellite measurements of recent volcanic activity at Oldoinyo Lengai, Tanzania
}

\author{
R. Greg Vaughan ${ }^{\text {a,* }}$, Matthieu Kervyn ${ }^{\text {b}}$, Vince Realmuto ${ }^{a}$, Michael Abrams ${ }^{\text {a }}$, Simon J. Hook ${ }^{\text {a }}$ \\ a California Institute of Technology, Jet Propulsion Laboratory, MS 183-501, 4800 Oak Grove Dr, Pasadena, CA 91109, USA \\ ${ }^{\mathrm{b}}$ Mercator E' Ortelius Research Centre for Eruption Dynamics, Department of Geology and Soil Sciences, Ghent University, Krijgslaan 281/S8, B-9000 Gent, Belgium
}

\section{A R T I C L E I N F O}

\section{Article history:}

Received 9 October 2007

Accepted 29 January 2008

Available online 29 February 2008

\section{Keywords:}

Oldoinyo Lengai

Thermal infrared remote sensing

ASTER

MODIS

volcanic ash plume

\begin{abstract}
A B S T R A C T
Oldoinyo Lengai $(\mathrm{OL})$ is the only active volcano in the world that produces natrocarbonatite lava. These carbonate-rich lavas are unique in that they have relatively low temperatures $\left(495-590{ }^{\circ} \mathrm{C}\right)$ and very low viscosity. OL has been erupting intermittently since 1983, mostly with small lava flows, pools and spatter cones (hornitos) confined to the summit crater. Explosive, ash-producing eruptions are rare, however, on September 4, 2007 the Advanced Spaceborne Thermal Emission and Reflection Radiometer (ASTER) captured the first satellite image of an ash plume erupting from OL, which may be indicative of a new phase of more silica-rich products and explosive activity that has not occurred since 1966-1967. In the months prior to the eruption, thermal infrared (TIR) satellite monitoring detected an increasing number of thermal anomalies around OL. Data from the Moderate Resolution Imaging Spectroradiometer (MODIS) sensor analyzed with the MODLEN algorithm detected more than 30 hot spots in the last week of August and first week of September 2007, some of which were from bush fires ignited by lava flows or spatter around the volcano. Higher-resolution ASTER data confirmed the location of these burn scars associated with lava flows. ASTER also detected the appearance of an anomalous hot spot at the summit of OL in mid-June with temperatures $\sim 440{ }^{\circ} \mathrm{C}$, the presence of several new lava flows in the crater in July and August, and on September 4 measured higher temperatures $\left(\sim 550{ }^{\circ} \mathrm{C}\right)$ possibly suggesting a more silicate-rich eruption. ASTER spectral emissivity data were interpreted to indicate a mixture of carbonate and silicate ash in the eruption plume from September 4. Based on the analysis of both ASTER and MODIS data combined with occasional field observations, there appear to have been 2 distinct eruptive events so far in 2007: a typical natrocarbonatite eruption confined to the summit crater in June-July, and a more intense eruption in August-September consisting of natrocarbonatite lava overflowing the crater and explosive events forming ash plumes up to $\sim 5 \mathrm{~km}$ high, apparently consisting of a mixture of silicate and carbonate ash. OL is one of the many volcanoes in the world, and especially Africa, that is not regularly monitored with in situ instruments. Continued satellite monitoring along with studies of past thermal activity will help determine how future eruptions and ensuing hazards may be forecasted.
\end{abstract}

(c) 2008 Elsevier B.V. All rights reserved.

\section{Introduction}

Oldoinyo Lengai (OL) is a stratovolcano located in Northwest Tanzania, Africa $\left(2.76{ }^{\circ} \mathrm{S} ; 35.914{ }^{\circ} \mathrm{E}\right)$ (Fig. 1). It has been the focus of numerous studies due to its uniqueness as it is the only volcano that produces natrocarbonatite lava with very low viscosity $\left(10^{-1}\right.$ to $10^{2} \mathrm{~Pa} s-$ compared to $10^{2}$ to $10^{4} \mathrm{~Pa}$ s for basalt) and low temperature $\left(495-590^{\circ} \mathrm{C}\right.$ - compared to $700-1200{ }^{\circ} \mathrm{C}$ for silicate lavas) (Dawson et al., 1968; Krafft and Keller, 1989; Dawson et al., 1990; Wolff, 1994; Pinkerton et al., 1995; Norton and Pinkerton, 1997; Oppenheimer, 1998). Occasionally OL has exhibited more silicate-rich natrocarbonatite eruptions (i.e., $3 \%$ silica instead of $<1 \%$ ), including lava flows in June 1993 and March 2006 (Nyamweru, 1990; Dawson et al., 1994; Pinkerton et al., 1995; Nyamweru, 1997; Oppenheimer, 1998; Klaudius and Keller, 2004; Kervyn et al., in press-a,b). Also, on at least three occasions during the last century (in 1917, 1940-41, and

\footnotetext{
* Corresponding author. Tel.: +1 6263194146.

E-mail address: vaughanrg@gmail.com (R.G. Vaughan).
}

1966-67) OL produced sub-plinian explosive silicate eruptions resulting in the dispersal of a mixture of silicate and carbonate ash up to $180 \mathrm{~km}$ away (Dawson et al., 1968; Nyamweru, 1990; Dawson et al., 1995). After the 1966-67 eruptions OL was quiescent for about 16 years, and then in 1983 began a phase of natrocarbonatite eruptions that produced numerous lava flows, lava pools, and spatter cones (hornitos) that filled up the 150-m-deep summit crater (Keller and Krafft, 1990; Nyamweru, 1990; Dawson et al., 1995). Thermal features in the summit crater typically consist of fumaroles, open vents, or cooling lava from small pools, flows or spatter (Fig. 2). Since 1998, there have also been several lava flows that overflowed the summit crater and traveled a few hundred meters down the east, north, and west flanks of the volcano (Nyamweru, 1997; GVN, 2000, 2002, 2003, 2004, 2005; Kervyn et al., 2006, in press-b). In MarchApril 2006, a 3-km-long lava flow formed on the west flank during the largest-volume natrocarbonatite eruption ever witnessed at OL (Kervyn et al., in press-b) (Fig. 2c).

As with most of the active volcanoes in Africa, OL is not routinely monitored with field instruments. Until more recent satellite monitoring the only information of activity came from sporadic (and 


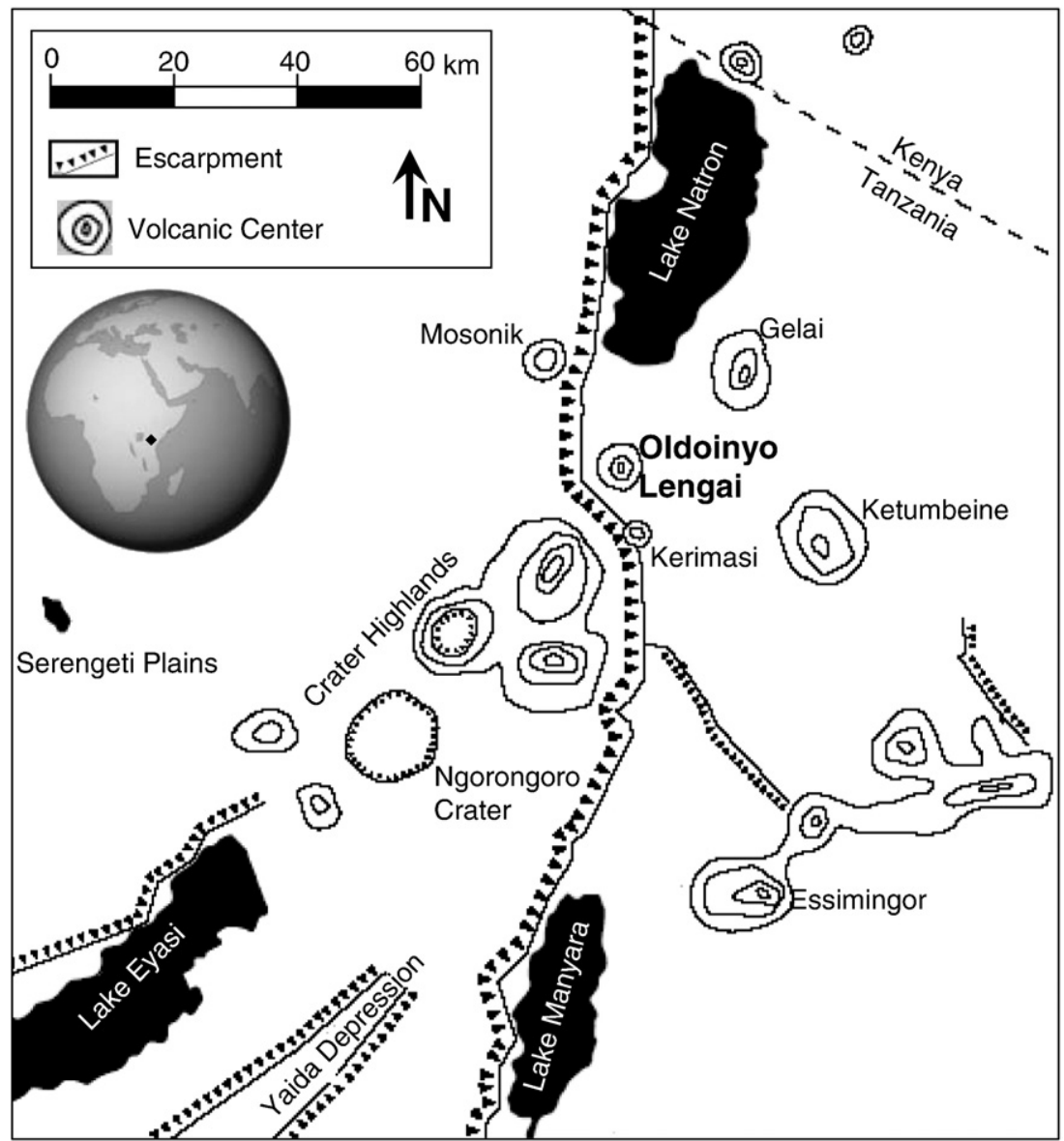

Fig. 1. Location of Oldoinyo Lengai and regional geology (from Kervyn et al., in press-a, modified from Dawson 1992).

occasionally inaccurate) reports from locals or tourists in the area (Oppenheimer 1998, Kervyn et al., in press-a). In mid-July 2007 there was a swarm of seismic activity in the region ( $>50$ events large enough to be detected by global seismic networks), including a magnitude 5.9 earthquake on July 17 less than $50 \mathrm{~km}$ northeast of OL. On July 19 some observations of an apparent ash plume at the summit led to local reports that OL was erupting explosively again, as it had been mistakenly reported in April 2006 (Kervyn et al., in press-b). In both cases, the small ash plume was caused by hornito collapse and pit crater formation within the summit active crater or small landslides along the steep upper flanks. The volcano was indeed active in July 2007, but not explosively and no lava was overflowing down the flanks. Satellite data from June to August 2007 confirm that thermal activity was confined to the summit. The exaggerated reports of personal injuries and evacuations due to an eruption were fortuitous however, because they prompted a closer look at OL. Subsequent satellite monitoring revealed significant thermal anomalies at the summit as early as June 2007, and on September 4, 2007, imaged a rare explosive eruption. In August and September there were several more seismic events in the Gelai region, $25 \mathrm{~km}$ northeast of OL. These events have been confirmed as relating to dike emplacement (Oyen et al., 2007). Whether the change in eruption style at OL, from natrocarbonatite lava flows to the more explosive event on September 4, 2007 is related to this concurrent seismic activity is still being investigated.

This paper presents the first ASTER-derived temperature estimations of thermal features at OL and the first satellite observations of ash emission from an explosive eruption of OL. Together with results of daily MODIS observations and field reports, this work also highlights the usefulness of satellite data to monitor this remote volcano.

\section{Physical basis}

The physical basis for remote temperature measurement is Planck's radiation law (see Dozier, 1981; Rothery et al., 1988; Gillespie et al., 1998). A material on the Earth's surface radiates energy in proportion to its temperature and emissivity. Emissivity is an intrinsic material property and independent of temperature, unless the material approaches near-molten temperatures, in which case there is an inverse relationship between temperature and emissivity (Abtahi et al., 2002). Radiance is not an intrinsic material property; it varies with wavelength and temperature, as well as environmental factors, such as solar irradiance history. As the temperature of a material increases, emitted radiance increases at all wavelengths, but not equally. According to Wien's law, the wavelength of maximum radiance shifts to shorter wavelengths with increasing temperature. The spectral radiance measured by an instrument is affected by three atmospheric parameters: (1) atmospheric path radiance (emitted directly into the sensor from the atmosphere); (2) atmospheric radiance reflected from the surface; and (3) atmospheric transmissivity. References to the methods used for atmospheric correction and separation of the temperature and emissivity components are mentioned in Section 3.

\section{Instrumentation, data and processing}

\subsection{ASTER}

The ASTER instrument is mounted on the Terra spacecraft and measures radiance in 14 spectral channels in the visible, near infrared 


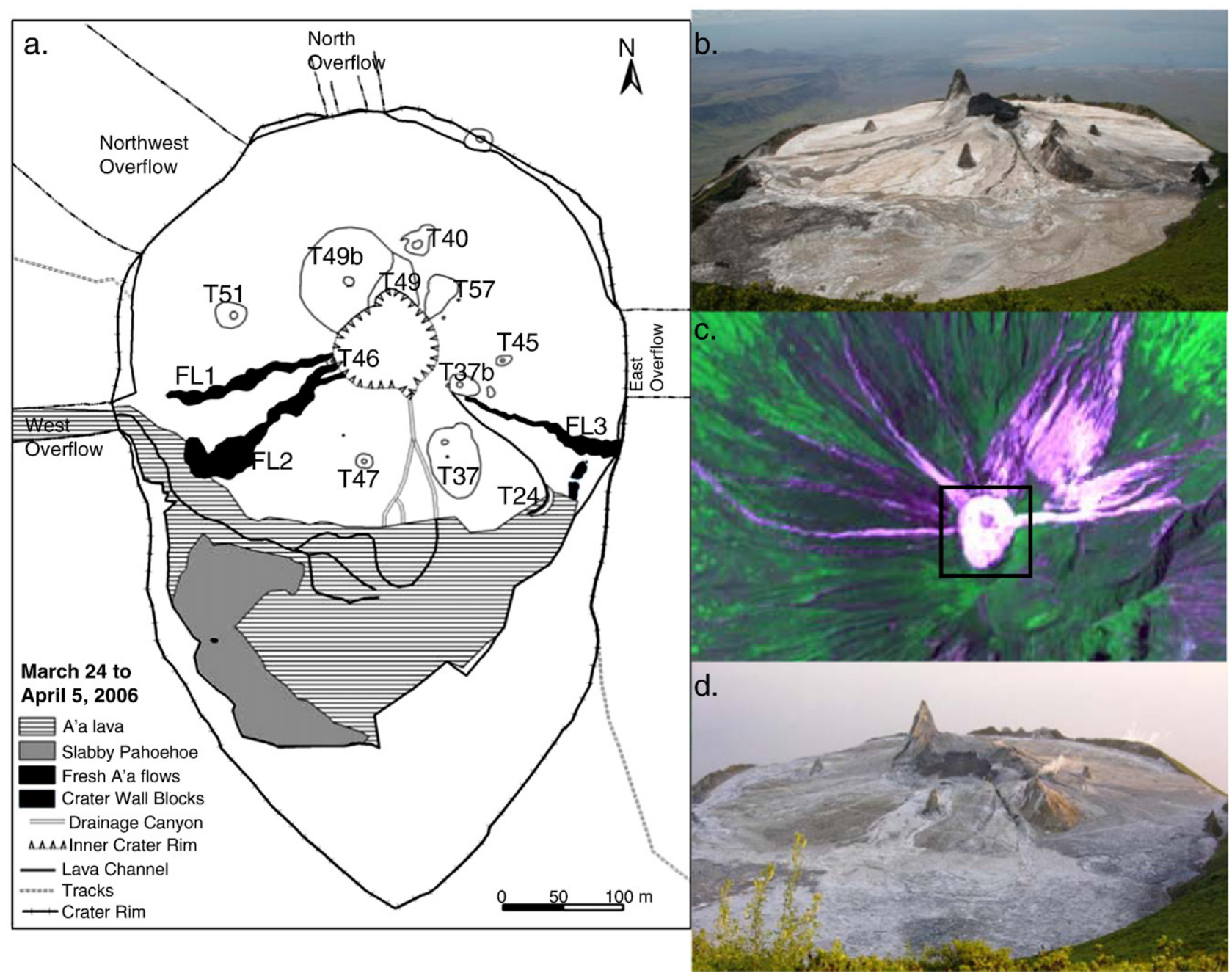

Fig. 2. (a) Map of volcanic features (e.g., hornitos and fresh lava flows) in the OL summit crater from March-April 2006. (b) Field photo of OL summit from May 21, 2006 (taken looking north) (photo courtesy Matthieu Kervyn). (c) ASTER image of OL from February 24, 2007 showing the extent of previous lava flows down the flanks. ASTER channels 2, 3, and 1 are R, $\mathrm{G}$, and B in this false color image (vegetated areas are bright green, relatively unvegetated rock/soil is purple, cooled lava flows that fill the crater are white. There was no volcanic thermal activity at this time. The box around the oval summit crater $\left(400 \times 500 \mathrm{~m}^{2}\right)$ highlights the area shown in Fig. 4. (d) Field photo of OL summit from June 18,2007 (taken looking north) (photo courtesy Rohit Nandedkar). The collapsed inner crater shows a crust of fresh (black) carbonatites, surrounded by tall hornitos.

(VNIR, 0.4-0.8 $\mu \mathrm{m}$ ), short wave infrared (SWIR, 1.4-2.5 $\mu \mathrm{m}$ ), and thermal infrared (TIR, 8-12 $\mu \mathrm{m}$ ) wavelength regions (Yamaguchi et al., 1998). The spatial resolution of the VNIR, SWIR and TIR channels are 15,30 and $90 \mathrm{~m}$, respectively.

To date, ASTER data have been acquired over OL on 12 occasions in 2007 (see Table 1). Three of the scenes were too cloudy to be of use; two of the scenes were partly cloudy, but clear enough to detect the presence or absence of thermal anomalies; five of the scenes were perfectly clear; and two scenes contained an ash plume that partially obscured the summit. Three of the clear scenes were acquired at night; the rest were day time scenes. ASTER SWIR data can be acquired with different radiometric gain settings to accommodate a wider range of surface radiances; for high-temperature volcanic targets data are commonly acquired in "volcano mode" (Wright et al., 1999). The night time SWIR data were acquired in volcano mode, which means that channels 4, 6, and 8 were recorded with the Low Gain 2 setting and channels 5, 7, and 9 with the High Gain setting. The daytime data were all acquired with Normal Gain settings. Atmospherically and cross-talk corrected surface radiance data (AST09XT for the VNIR/ SWIR channels; AST09T for the TIR channels) were used to measure surface radiance variations and calculate the characteristics of the thermal features using a 2-component temperature unmixing model (described below). The methods for atmospheric correction and the SWIR cross-talk correction used to produce the AST09XT and AST09T data products are described in Thome et al. (1998) and Tonooka and Iwasaki (2003). In addition, ASTER surface kinetic temperature data (AST08), derived using the temperature-emissivity separation $(\mathrm{T} \varepsilon S$ ) method of Gillespie et al. (1998) were used to determine 90-m pixelintegrated temperatures (PIT) of the thermal features and the surrounding (cooler) background areas.

The typical mineralogy of natrocarbonatite lavas from OL includes: Nyerereite $\left(\mathrm{Na}_{2} \mathrm{Ca}\left(\mathrm{CO}_{3}\right)_{2}\right)$, gregoryite $\left(\mathrm{Na}_{1.2} \mathrm{~K}_{0.6} \mathrm{Ca}_{0.1}\left(\mathrm{CO}_{3}\right)\right)$, sylvite $(\mathrm{KCl})$, and fluorite $\left(\mathrm{CaF}_{2}\right)$ (Dawson et al., 1990; Keller and Krafft, 1990; Oppenheimer, 1998). However, upon exposure to humid air these minerals hydrate to minerals such as: gaylussite $\left(\mathrm{Na}_{2} \mathrm{Ca}\left(\mathrm{CO}_{3}\right)_{2}\right.$ $\left.5 \mathrm{H}_{2} \mathrm{O}\right)$, nahcolite $\left(\mathrm{NaHCO}_{3}\right)$, and pirssonite $\left(\mathrm{Na}_{2} \mathrm{Ca}\left(\mathrm{CO}_{3}\right)_{2} 2 \mathrm{H}_{2} \mathrm{O}\right)$ (Dawson et al., 1987; Keller and Krafft, 1990; Koberski and Keller, 1995; Zaitsev and Keller, 2006). There are no known laboratory spectral measurements for any of these minerals except for gaylussite. Therefore, the spectral emissivities that were assumed for radiometric temperature calculations and sub-pixel thermal modeling were derived from laboratory spectral measurements of gaylussite resampled to the spectral response functions of ASTER (see ASTER spectral library:http://speclib.jpl.nasa.gov). Although work by Abtahi 
Table 1

Summary of ASTER observations over OL in 2007

\begin{tabular}{|c|c|c|c|c|c|c|c|c|}
\hline \multirow[t]{2}{*}{ Date } & \multicolumn{2}{|c|}{ Comments } & \multirow{2}{*}{$\begin{array}{l}\text { Thermal } \\
\text { anomaly }\end{array}$} & \multirow{2}{*}{$\begin{array}{l}\text { Back- } \\
\text { ground } \\
\text { T\&S PIT } \\
\left({ }^{\circ} \mathrm{C}\right)\end{array}$} & \multirow{2}{*}{$\begin{array}{l}\text { Max } \\
\mathrm{T} \varepsilon S \\
\text { PIT } \\
\left({ }^{\circ} \mathrm{C}\right)\end{array}$} & \multirow{2}{*}{$\begin{array}{l}\text { Temperature } \\
\text { hot fraction } \\
\left({ }^{\circ} \mathrm{C}\right)\end{array}$} & \multirow{2}{*}{$\begin{array}{l}\text { Area hot } \\
\text { fraction } \\
\left(\mathrm{m}^{2}\right)\end{array}$} & \multirow{2}{*}{$\begin{array}{l}\text { Max } \\
\text { PIT } \\
\left({ }^{\circ} \mathrm{C}\right) \\
(\mathrm{SWIR})\end{array}$} \\
\hline & & & & & & & & \\
\hline $1 / 23$ & Day & Clear & & 26.7 & 31.4 & NA & NA & NA \\
\hline $2 / 15$ & Day & $\begin{array}{l}\text { Too } \\
\text { cloudy }\end{array}$ & & & & & & \\
\hline $2 / 24$ & Day & Clear & & 34.9 & 41.8 & NA & NA & NA \\
\hline $3 / 14$ & Night & $\begin{array}{l}\text { Too } \\
\text { cloudy }\end{array}$ & & & & & & \\
\hline $4 / 15$ & Night & $\begin{array}{l}\text { Thin } \\
\text { clouds }\end{array}$ & Weak & 8.3 & 18.6 & NA & NA & 90.0 \\
\hline $6 / 18$ & Night & Clear & Intense & 11.8 & 45.1 & 438.6 & 81.0 & 303.4 \\
\hline $7 / 20$ & Night & $\begin{array}{l}\text { Thin } \\
\text { clouds }\end{array}$ & Moderate & 10.7 & 26.2 & 222.5 & 267.3 & 202.5 \\
\hline $7 / 25$ & Day & Clear & Intense & 36.6 & 66.8 & 390.8 & 226.8 & NA \\
\hline $8 / 3$ & Day & Clear & Moderate & 37.7 & 48.8 & 207.9 & 334.8 & NA \\
\hline $8 / 14$ & Night & $\begin{array}{l}\text { Too } \\
\text { cloudy }\end{array}$ & & & & & & \\
\hline $9 / 4$ & Day & $\begin{array}{l}\text { Ash } \\
\text { plume }\end{array}$ & Intense & 38.9 & 88.5 & 547.6 & 319.1 & NA \\
\hline $9 / 11$ & Day & $\begin{array}{l}\text { Ash } \\
\text { plume }\end{array}$ & Intense & 37.3 & 56.8 & 334.88 & 378.0 & NA \\
\hline
\end{tabular}

et al. (2002) indicates that emissivities for molten and nearly molten volcanic rocks do show a temperature-dependence, there are currently no data that can be used to quantify this effect for OL lavas.

Lava flows at OL are typically much smaller in volume and aerial extent (e.g., a few meters wide and a few hundred meters long) than the large lava flow fields (hundreds of meters wide and many kilometers long) typical of, for example, Mount Etna (Lombardo et al., 2004) or Kilauea (Byrnes et al., 2004). Thus, the volcanic thermal features at $\mathrm{OL}$ are typically smaller in area than the pixel sizes acquired from spaceborne sensors (even with relatively high-spatial resolution measurements: $<100-\mathrm{m}$ pixels). At the summit of OL, there are numerous sub-pixel sized thermal features including fumaroles, lava pools, and hornitos. A method for calculating the fractional area and temperature of sub-pixel thermal components using concurrent multispectral measurements was first described by Dozier (1981), who used a "dual-band" method to unmix sub-pixel thermal components. Several studies have further developed this method (Rothery et al., 1988; Crisp and Baloga, 1990; Pieri et al., 1990; Oppenheimer et al., 1993; Wooster and Rothery, 1997; Harris et al., 1999; Wright et al., 2000; Lombardo and Buongiorno, 2003; Pieri and Abrams, 2005).

Following the methods of Rothery et al. (1988) and Harris et al. (1999) a 2-component system was assumed, where one pixel can be modeled with two temperature components (one very hot and one representative of the cooler background temperature). If either one of the two unknown temperature components can be assumed or measured independently, then the other temperature and the subpixel areas of each temperature component can be calculated. For the case at $\mathrm{OL}$, the temperature of the cooler background area was assumed by using ASTER surface kinetic temperature measurements of the area around, but not containing, thermal features at the summit. This allowed a solution for the unknown maximum temperature within a pixel. Although the 2-component model is usually an oversimplification of the thermal structure of a pixel (Wright and Flynn 2003), it is a necessary assumption when there are no independent measurements of lava temperature-area parameters necessary to solve a more complex system. Because of this, we consider the hot fraction temperatures, determined using the 2-component method, to be average temperatures of a hot fraction and therefore underestimates of the actual maximum temperature within the pixel.

\subsection{MODIS}

The Moderate Resolution Imaging Spectrometer (MODIS) is a companion instrument to ASTER on the Terra spacecraft (launched in 1999) and another MODIS instrument is on the Aqua spacecraft (launched in 2002). MODIS measures radiance in 36 spectral channels in the VNIR/SWIR (0.4-2.5 $\mu \mathrm{m})$, mid-wave infrared (MIR - 3.7-4.5 $\mu \mathrm{m}$ ) and TIR (7.2-14.1 $\mu \mathrm{m})$ wavelength regions (Salomonson et al., 1989). All of the MODIS MIR and TIR channels used for hot spot detection have a 1-km spatial resolution. Unlike ASTER, MODIS data are acquired almost continuously, and with a wide swath $(2330 \mathrm{~km})$ MODIS data cover almost every square $\mathrm{km}$ of the Earth's surface twice each day (once during the day and once at night). As a result, temporal coverage
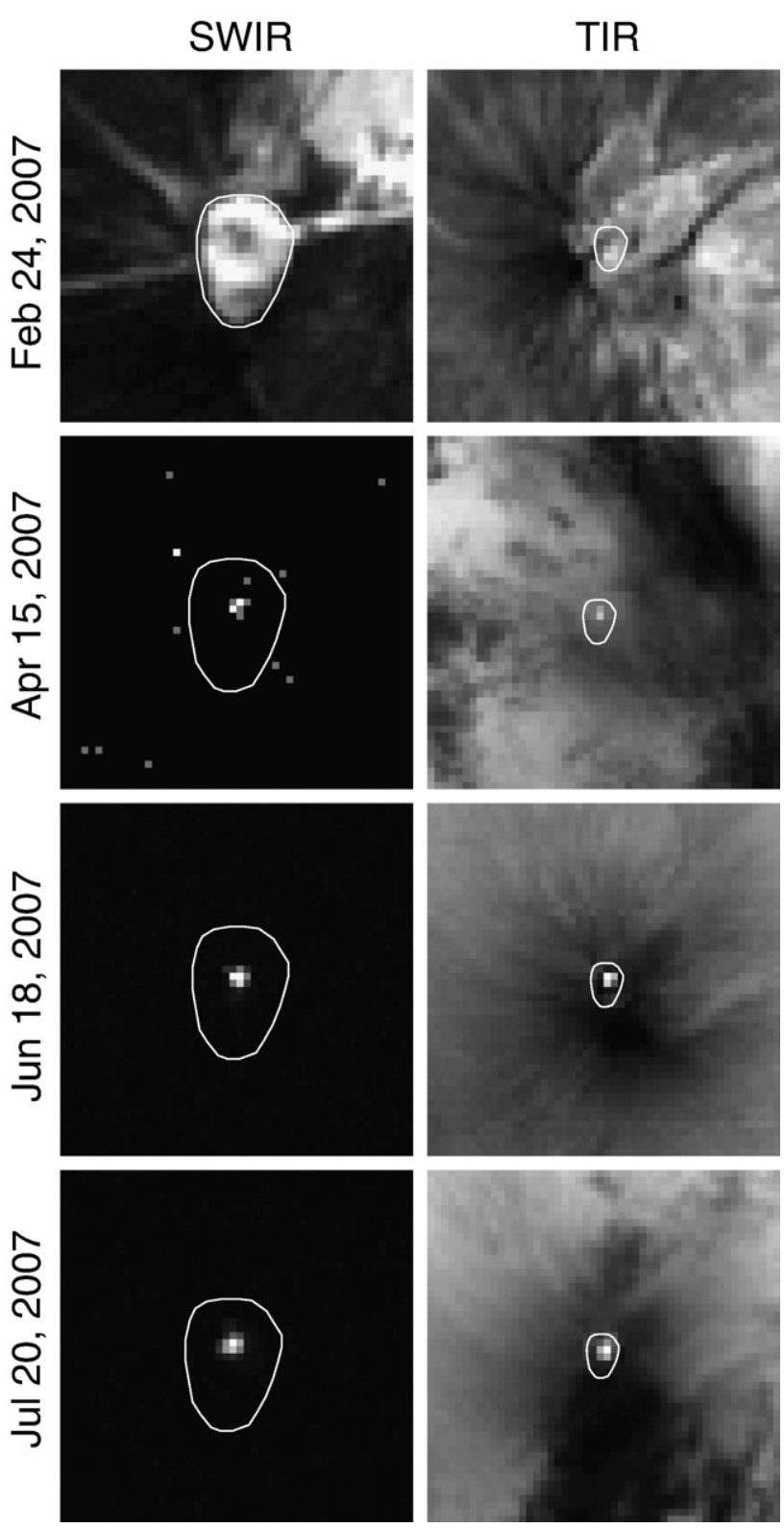

Fig. 3. Mosaic of ASTER images from February 24 (daytime), April 15, June 18, and July 20, 2007 - all nighttime images except February 24. For each date the first column of images shows the SWIR channel $9(2.40 \mu \mathrm{m})$ radiance data, where bright pixels represent high solar reflected radiance in the daytime data, but represent high thermal emission in the nighttime images. The second column shows the TIR channel 13 $(10.66 \mu \mathrm{m})$ radiance data, where bright pixels represent high thermal emission areas. The white outlines show the approximate extent of the OL summit crater (about $400 \mathrm{~m}$ across). North is up in all images. 
of volcanic targets like OL is limited only by cloud cover. To detect global thermal anomalies and automatically extract information about them from such a large data set a method for quickly and efficiently analyzing the data was developed: MODVOLC (Flynn et al., 2002; Wright et al., 2004). The MODVOLC method uses the radiance data from the MIR (ch22 - $3.95 \mu \mathrm{m})$ and TIR (ch32 - $12 \mu \mathrm{m})$ regions to define a normalized thermal index (NTI) for each pixel: NTI $=(\operatorname{ch} 22-$ $\operatorname{ch} 32) /(\operatorname{ch} 22+\operatorname{ch} 32)$. If channel 22 is saturated, channel 21 is used instead (Wright et al., 2004). An NTI value of -0.8 has been routinely used as a threshold, above which a thermal anomaly is reported. This threshold was designed to minimize false alerts; as a result, however, the technique misses subtle thermal anomalies that are real. A technique designed to increase sensitivity to subtle hot spots has been developed: MODLEN (Kervyn et al., 2006, in press-b). MODLEN is an adaptation of the MODVOLC algorithm designed to detect lowintensity thermal anomalies at OL. MODLEN was designed to focus on a specific volcanic target, in this case a $12 \times 12 \mathrm{~km}^{2}$ region around OL. It uses the same NTI definition plus baseline radiance data for the target, contrasting radiance data from the surrounding pixels, and lowers the NTI threshold to -0.83 and -0.88 in case spatial derivation indicates significant thermal deviation relative to the surrounding pixel (Kervyn et al., 2006, in press-b).
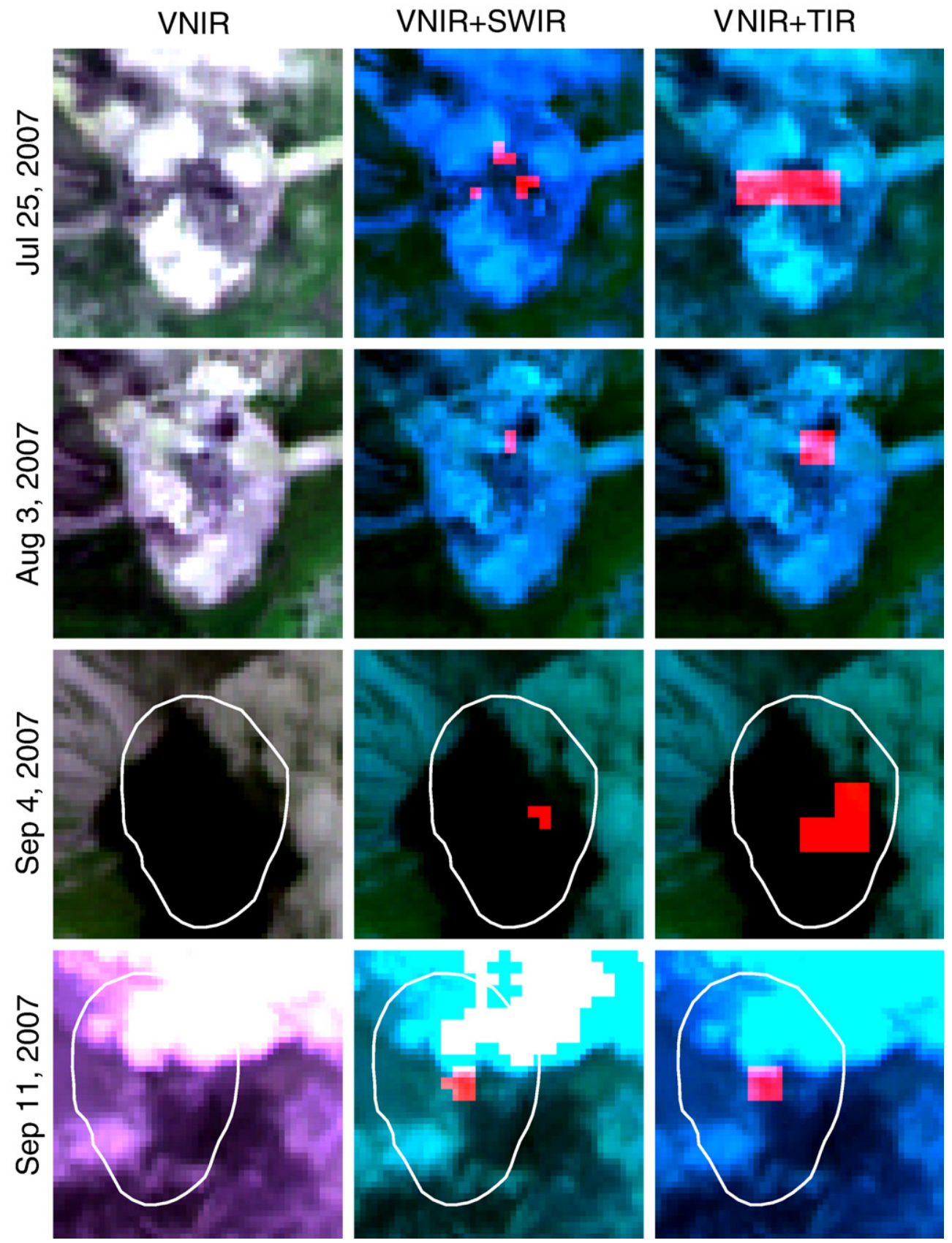

Fig. 4. Mosaic of ASTER images zooming in on the summit crater area from July 25, August 3, September 4, and September 11 , 2007 - all daytime images. For each date, the first column of images shows a VNIR image (channels 2-3-1 as red-green-blue) of the summit crater. Fresh natrocarbonatite lava is black; hydrated Na-carbonate minerals, representative of cooled lava, are white and generally fill the summit crater. In the 2nd and 3rd columns VNIR channels 3 and 1 are green and blue, respectively, and to enhance the hot spot locations, the red color is driven by SWIR channel $9(2.40 \mu \mathrm{m})$ radiance in column 2 and TIR channel $13(10.66 \mu \mathrm{m})$ radiance in column 3 . For the last 2 dates when the summit crater was not clearly visible, white outlines show the extent of the crater. Note that the sizes of the hot spots (red) reflect the 30-m spatial resolution of the SWIR data (column 2), and the $90-\mathrm{m}$ spatial resolution of the TIR data (column 3). Also note how accurately the VNIR, SWIR and TIR data are co-registered to each other in daytime ASTER data. The OL summit crater is about $400 \mathrm{~m}$ across and north is up in all images. 


\section{Results and interpretation}

\subsection{ASTER}

Daytime ASTER data from January and February 2007 showed no evidence of significant thermal activity at the summit of OL. The TIR temperature data exhibited temperatures due to solar heating and the VNIR data showed the crater almost entirely filled with cooled and altered (white) lava flows (Fig. 2c). During this quiescent time the only surface expression of thermal activity was from fumaroles and open vents that radiate heat away from lava pools in the shallow subsurface. Unconfirmed reports from visitors to the volcano summit during these months stated that rumbling lava could be heard beneath the surface (B. Masson and T. Docks, personal communication, 2007). During the daytime, the minor volcanic heating at the surface due to fumaroles and open vents may be too subtle to be separated from heat due to solar irradiation. The daytime TIR data from February 24 measured a maximum temperature of $42{ }^{\circ} \mathrm{C}$, just $7{ }^{\circ} \mathrm{C}$ above the average background surface temperature (Table 1; Fig. 3). Nighttime data, however, are more apt to detect subtle thermal activity, for example the ASTER scene from April 15, 2007 (Fig. 3). Although this nighttime scene was partly cloudy, enough radiance from the surface was transmitted through the thin clouds to identify two TIR and two SWIR pixels that were significantly brighter than the surrounding pixels. In the SWIR data some random pixel noise was evident due to the contrast stretch; however, the cluster of pixels including the two brightest pixels indicated the location of the crater. The presence of thin clouds prevented the accurate determination of surface temperature, but the fact that all the TIR channels (10-14) and SWIR channels 7 and 9 measured radiances that were higher than the surrounding background areas suggested that there were thermal features at the summit that were at least $90-100{ }^{\circ} \mathrm{C}$. This may be representative of normal background activity that can only be detected at night - perhaps due to venting fumaroles, a collapsed hornito opening a conduit to hot lava below, or generally elevated ground temperatures due to the presence of shallow magma.

In the clear nighttime ASTER image from June 18, there was a strong thermal anomaly at the summit of OL (Fig. 3). The ASTER T $\varepsilon S$ PIT of the brightest TIR pixel was $45{ }^{\circ} \mathrm{C}$ (compared to $12{ }^{\circ} \mathrm{C}$ for the surrounding area). ASTER SWIR channel $4(1.655 \mu \mathrm{m})$ also detected anomalously high emitted radiance corresponding to a 30 -m PIT of $\sim 303^{\circ} \mathrm{C}$. Based on subpixel temperature modeling of the brightest TIR pixel, the highest temperature component of the pixel was $439{ }^{\circ} \mathrm{C}$ and covered $\sim 81 \mathrm{~m}^{2}$. Around this time (June 17-20) a group of people at the OL summit observed numerous venting fumaroles, boiling lava pools in the central crater, and active spatter cones splashing lava up to 15-20 m high $(\mathrm{H}$. Mattsson, personal communication, 2007, Fig. 2d). The next available night time ASTER scene from July 20 was partly cloudy; however, radiances that were distinctly above-background were measured in all of the TIR and SWIR channels (except channel 4). Lack of emissive radiance in channel 4 suggested a maximum temperature less than $\sim 233{ }^{\circ} \mathrm{C}$ (the minimum measurable PIT with this channel given the assumed channel 4 spectral emissivity of gaylussite (0.86) and the Low Gain 2 setting (Wright et al., 1999)). The radiometric temperature calculated from SWIR channel $6(2.2 \mu \mathrm{m})$, assuming the emissivity of gaylussite (0.92), was $203{ }^{\circ} \mathrm{C}$ and the TIR sub-pixel temperature model yielded a maximum temperature of $222.5{ }^{\circ} \mathrm{C}$ covering an area of $\sim 267 \mathrm{~m}^{2}$ (see Table 1). These temperatures are reasonable for cooling lava at the surface, but could also be underestimated due to the thin clouds.

Fig. 4 is an image mosaic that shows the spatial relationships of the thermal anomalies for the four daytime scenes acquired from July 25 to September 11, 2007. For each date a VNIR false color image of the OL summit crater is shown in the first column. In these images, channels 2,3 , and 1 are displayed as $R, G$, and B and the spatial resolution is $15 \mathrm{~m}$. In the July and August images, the light-colored alteration products of the natrocarbonatite lava that fills the summit crater can be seen along with some darker material, which were recent lava flows emplaced to the N, SE and WSW of the central pit crater. Based on field observations on July 22-23, there were two active spatter cones and lava flows on the SE side of the central crater, a recent a'a flow on the north side, and recent flows on the WSW side (Belton, 2007). All lava flows were confined to the summit area at this time. These three directions of lava flows away from the central crater are evident as distinct hot spots in the VNIR+SWIR false color image (second column of Fig. 4). On August 3, there was a circular dark area on the north side of the crater that was not there in the previous image. This area corresponded to SWIR and TIR hot spots and was interpreted to be a new lava flow or lava pool. In the September 4 image the gray ash plume (discussed below) casts a shadow on much of the summit crater (outline in white), however hot spots are exposed next to the plume (the presence of the shadow blocks much of the reflected solar radiance from this area, making the hot spots more evident, particularly in the SWIR data). Finally, in the September 11 image a mixture of ash, meteorological clouds and/or volcanogenic steam obstructed the view of the crater, but thermal hot spots in both SWIR and TIR data revealed the location of the heat source in the central region of the crater.

A plot of the ASTER-derived temperatures (from Table 1) is shown in Fig. 5, including $\mathrm{T} \varepsilon \mathrm{S}$-derived pixel-integrated temperature (PIT) for the background and the single brightest pixel; SWIR-derived PIT (for the night time data only); and the high-temperature components from the TIR sub-pixel modeling. Thermal anomalies were most evident when the maximum $\mathrm{T} \varepsilon \mathrm{S}$ temperature was at least $10^{\circ} \mathrm{C}$ above the average background temperature. For any given date, it is expected for the TES PITs to be the lowest, the SWIR radiometric PITs to be higher and the TIR sub-pixel high-temperature components to be the highest. This is because TIR radiances are integrated over $90-\mathrm{m}$ pixels and in the TIR region, part of the emitted radiance is from cooler background materials. In the SWIR wavelength range only hightemperature materials $\left(>\sim 95{ }^{\circ} \mathrm{C}\right)$ will be emitting measurable radiance, but the SWIR radiometric temperatures are also PITs, integrated over $30-\mathrm{m}$ pixels. Therefore, we hypothesize that the

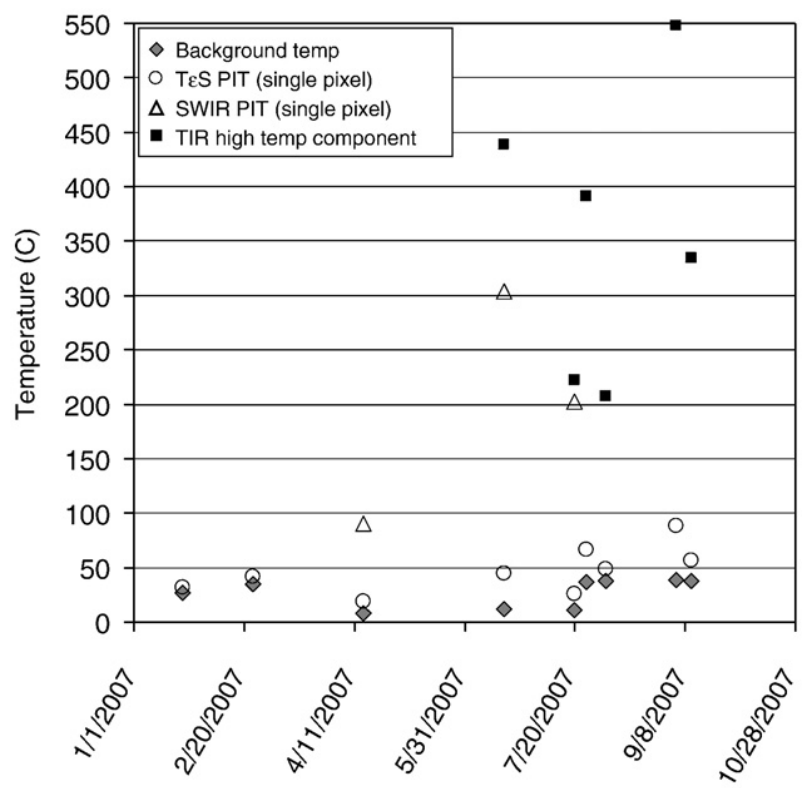

Fig. 5. Plot of ASTER temperature measurements and temperature changes in 2007 (see Table 1). TES-derived background temperatures were averaged over multi-pixel areas; $\mathrm{T} \varepsilon S$ PITs are maximum single-pixel temperatures (90-m pixel); SWIR PIT are radiometric temperatures averaged for all SWIR channels, derived using the normalized emissivity method and are for the single hottest pixel (30-m pixel); and the TIR hightemperature components were derived using a 2-channel sub-pixel unmixing model. 
sub-pixel temperatures derived using the TIR data may be closer to the actual values for the hottest fractions of the pixel, and even these may be underestimated because of the 2-component assumption.

The high-temperature components were variable (from 207 to $547^{\circ} \mathrm{C}$ ), but could be interpreted as being consistent with natrocarbonatite eruption temperatures $\left(495-590^{\circ} \mathrm{C}\right)$. Assuming that molten lava was exposed at the surface only for a short time before a cooler outer crust is formed; it is likely that measured temperatures were representative of variably cooling natrocarbonatite lava and thus cooler than predicted molten lava temperatures. Partial cloudiness may have affected the derived temperature on July $20\left(222.5^{\circ} \mathrm{C}\right)$, resulting in underestimation. However, the relatively low temperature measured under clear conditions on August $3\left(207.9^{\circ} \mathrm{C}\right)$ appears to be accurate and may represent a lava flow that formed a few days earlier. There are field reports of an a'a flow that had formed on the northern side of the crater around July 19 and on July 23 field observations of this flow indicated that it was still warm and showed no signs of alteration (Belton, 2007). The highest temperature observed $\left(547^{\circ} \mathrm{C}\right)$ on September 4, could be interpreted as a rare snapshot of molten natrocarbonatite lava at the surface, or a cooler crust of hotter, more silicate-rich lava.

In this short ASTER time-series, significant thermal activity began on June 18, 2007 and appeared to continue into September. It is important to note, however, that the low frequency of ASTER acquisitions results in a discontinuous time-series of measurements and that the more continuous, measurements by MODIS appear to distinguish two separate thermal events (discussed below).

\subsection{MODIS}

No sign of thermal activity was detected with MODIS data in 2007, until June 20. Despite occasional cloud masking, this suggests that no significant emission of lava occurred in the first few months of 2007, consistent with ASTER observations and field reports. The first MODLEN alert occurred on June 20, 2007, corresponding closely with the first ASTER detection of activity on June 18 (Fig. 6). This activity was also observed by a field party around June 17-20 (H.
Mattsson, personal communication, 2007). A period of intense thermal activity was recorded until July 7 , with continuous detection of thermal anomalies by MODLEN. A maximum of three thermally anomalous pixels was recorded on each scene with MODLEN. MODVOLC detected one third of the 30 thermal anomalies detected by MODLEN. The activity during that period was mostly concentrated within the central collapse pit inside the active summit crater, with spattering hornitos and lava covering the pit crater floor repetitively. From July 8 to August 20, activity at OL was low to moderate. Unambiguous thermal activity was only detected on July 23-25 and August 7-12. These low level thermal anomalies suggest eruptions of small volume lava flows that cooled to below detection limits within a day or two.

Thermal activity increased abruptly on August 21 (Fig. 6; Table 2). This increase took place after two magnitude 5 earthquakes occurred in the region on August 18 and 20; an additional earthquake occurred on August 24. In the few days after August 21, thermal anomalies affected up to 4 pixels around the summit, with increasing intensity. Multiple thermal anomalies were detected on August 24 and 25 at the summit and along the $\mathrm{E}$ and WNW flanks to a distance of $\sim 5 \mathrm{~km}$ from the summit. This was interpreted to be intense lava emissions which overflowed the crater rim and ignited bush fires along the volcano flanks. Activity was concentrated within the crater after August 25, but there were continued thermal anomalies on the lower flanks, probably associated with propagating bush fires. Activity peaked again on August 28-September 1, first with intense thermal anomalies in the crater, followed by multiple thermal anomalies on the NW flank to a distance of $3 \mathrm{~km}$ from the summit, again probably due to lavaignited bush fires. This was corroborated by pictures from a tourist attempting to climb OL during the night of September 2-3. They witnessed lava overflowing the crater rim on the NW side and bush fires developing along the lower flank (Belton, 2007). Thermally anomalous pixels were detected at the crater and along the flanks until September 3.

The start of explosive eruptions on September 4 marked the end of intense thermal activity. Masking by ash and/or meteoric clouds prevented identification of thermal activity within the crater by

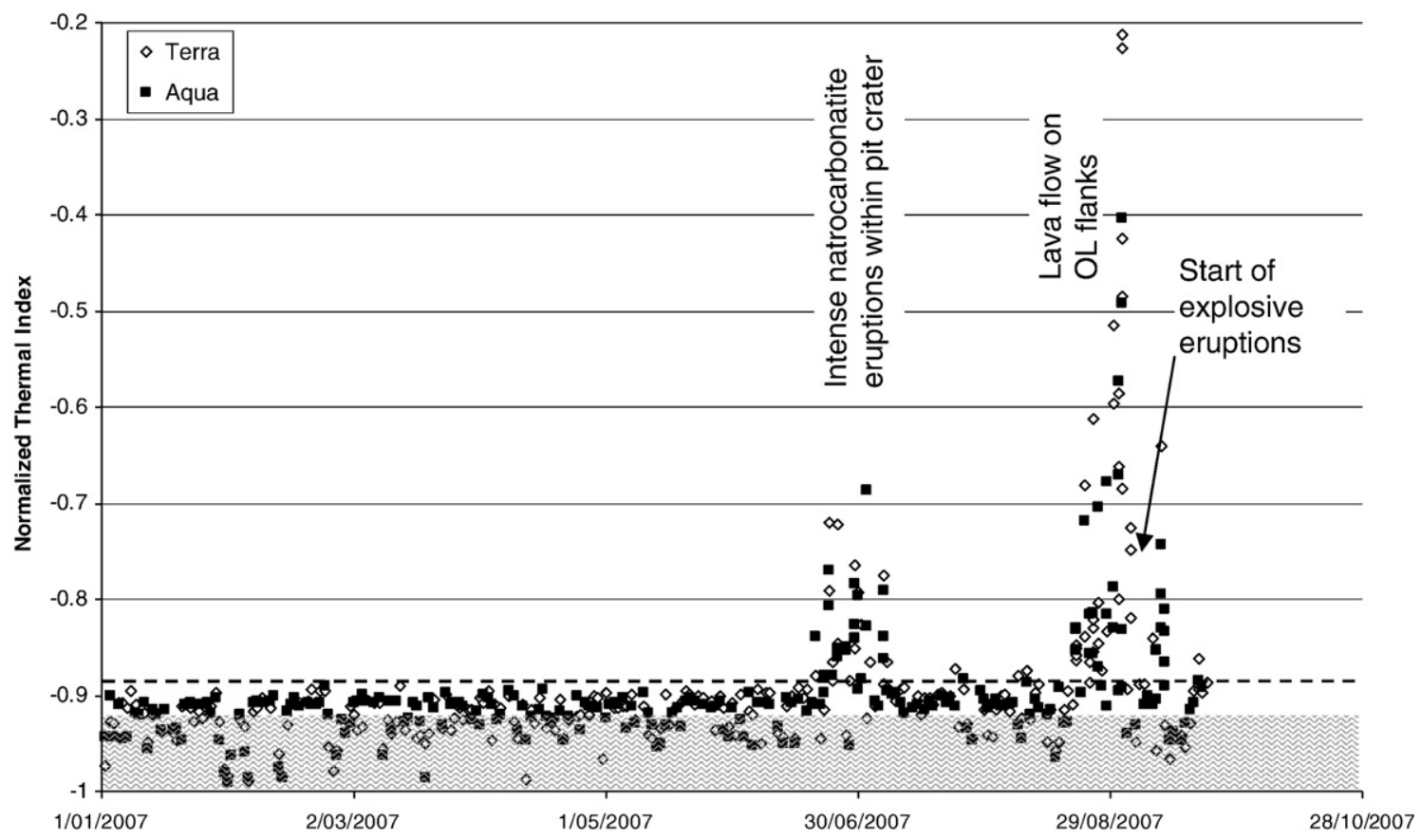

Fig. 6. Time series of normalized thermal index (NTI) values for the crater, extracted from MODIS nighttime images using the MODLEN algorithm (see Kervyn et al., 2008a), including all MODLEN alerts within $3 \mathrm{~km}$ of the summit from January 1 to September 12, 2007. NTI values above [-0.88] (stippled line) denote eruptive activity in progress whereas NTI values below [-0.92] (hatched area) are characteristic for clouds masking the summit. Data were acquired for the night between the plotted date and following day. 
Table 2

Summary of observations and interpretation of nighttime MODIS TIR data with the MODLEN and MODVOLC algorithms. All pixels identified as thermally anomalous within 5 km of OL summit are listed. Times are given in G.M.T.

\begin{tabular}{|c|c|c|c|c|}
\hline Date & $\begin{array}{l}\text { MODLEN } \\
\text { detected } \\
\text { anomalies }\end{array}$ & $\begin{array}{l}\text { MODVOLC } \\
\text { detected } \\
\text { anomalies }\end{array}$ & Level and localization of thermal signal & Interpretations \\
\hline $\begin{array}{l}\text { Aug } \\
21\end{array}$ & $\begin{array}{l}\text { Terra: } 4 \text { pixels } \\
\text { (8:05 pm) } \\
\text { Aqua: } 4 \text { pixels } \\
(11: 05 \mathrm{pm})\end{array}$ & - & Moderate anomalies at or close to OL summit & Start of increase in eruptive activity \\
\hline $\begin{array}{l}\text { Aug } \\
23\end{array}$ & $\begin{array}{l}\text { Terra: } 2 \text { pixels } \\
\text { (7:55 pm) } \\
\text { Aqua: } 1 \text { pixel } \\
(10: 50 \mathrm{pm})\end{array}$ & $\begin{array}{l}1 \text { pixel } \\
1 \text { pixel }\end{array}$ & Intense anomaly at summit & Active lava lake within summit pit crater \\
\hline $\begin{array}{l}\text { Aug } \\
24\end{array}$ & $\begin{array}{l}\text { Terra: } 2 \text { pixel } \\
\text { (8:35 pm) } \\
\text { Aqua: } 3 \text { pixels } \\
(11: 35 \mathrm{pm})\end{array}$ & - & $\begin{array}{l}\text { Moderate anomaly at summit and at } 2-4 \mathrm{~km} \\
\text { on E flank }\end{array}$ & Eruptive activity within the crater and bush fire on E flank \\
\hline $\begin{array}{l}\text { Aug } \\
25\end{array}$ & $\begin{array}{l}\text { Terra: } 5 \text { pixels } \\
\text { (7:40 pm) } \\
\text { Aqua: } 2 \text { pixels } \\
(10: 40 \mathrm{pm})\end{array}$ & $\begin{array}{l}2 \text { pixels } \\
-\end{array}$ & $\begin{array}{l}\text { Intense anomalies on E flank; moderate anomalies } \\
\text { at summit and on upper WNW flank }\end{array}$ & Lava overflow on E and WNW flanks; extending bush fire on E flank \\
\hline $\begin{array}{l}\text { Aug } \\
26\end{array}$ & $\begin{array}{l}\text { Terra: } 3 \text { pixels } \\
\text { (8:25 pm) } \\
\text { Aqua: } 1 \text { pixel } \\
(11.20 \mathrm{pm})\end{array}$ & 1 pixel & Intense anomalies at or close to active crater & New lava flow emplaced within crater; possible active lava lake \\
\hline $\begin{array}{l}\text { Aug } \\
27\end{array}$ & $\begin{array}{l}\text { Terra: } 2 \text { pixels } \\
(7: 30 \mathrm{pm})\end{array}$ & - & Weak anomalies at summit and W flank & Cooling lava flow in crater and waning bush fires \\
\hline $\begin{array}{l}\text { Aug } \\
28\end{array}$ & $\begin{array}{l}\text { Terra: } 1 \text { pixels } \\
\text { (8:15 pm) } \\
\text { Aqua: } 2 \text { pixels } \\
(11: 10 \mathrm{pm})\end{array}$ & 1 pixel & Intense anomalies at or close to summit & New lava flow emplaced within crater; possible active lava lake \\
\hline $\begin{array}{l}\text { Aug } \\
30\end{array}$ & $\begin{array}{l}\text { Terra: } 2 \text { pixels } \\
\text { (8:00 pm) } \\
\text { Aqua: } 2 \text { pixels } \\
(11: 00 \mathrm{pm})\end{array}$ & $\begin{array}{l}2 \text { pixels } \\
1 \text { pixel }\end{array}$ & Intense to very intense anomalies at summit & Voluminous lava emission within crater \\
\hline $\begin{array}{l}\text { Aug } \\
31\end{array}$ & $\begin{array}{l}\text { Terra: } 3 \text { pixels } \\
\text { (8:45 pm) } \\
\text { Aqua: } 2 \text { pixels } \\
(11: 40 \mathrm{pm})\end{array}$ & $\begin{array}{l}2 \text { pixels } \\
2 \text { pixels }\end{array}$ & $\begin{array}{l}\text { Intense to very intense anomalies at summit, } \\
\text { E and NW flanks }\end{array}$ & Voluminous lava emission within crater and lava overflowing on E and NW flanks \\
\hline $\begin{array}{l}\text { Sept } \\
1\end{array}$ & $\begin{array}{l}\text { Terra: } 10 \text { pixels } \\
(7: 50 \mathrm{pm}) \\
\text { Aqua: } 4 \text { pixels } \\
(10: 45 \mathrm{pm})\end{array}$ & $\begin{array}{l}10 \text { pixels } \\
2 \text { pixels }\end{array}$ & $\begin{array}{l}\text { Very intense anomalies at summit and along NW } \\
\text { flanks to a distance of } 4 \mathrm{~km}\end{array}$ & Voluminous lava overflow on NW flank starting bush fires on the flanks \\
\hline $\begin{array}{l}\text { Sept } \\
3\end{array}$ & $\begin{array}{l}\text { Terra: } 3 \text { pixels } \\
(7: 35 \mathrm{pm})\end{array}$ & 2 pixels & $\begin{array}{l}\text { Moderate anomaly at summit and intense anomalies } \\
\text { on W flank }\end{array}$ & Cooling lava at summit; lava overflow and bushfire on W flank \\
\hline $\begin{array}{l}\text { Sept } \\
4\end{array}$ & $\begin{array}{l}\text { Sept 8: } 1 \text { pixel } \\
\text { (Terra) } \\
\text { Sept 9: } 1 \text { pixel } \\
\text { (Aqua) } \\
\text { Sept 10: } 1 \text { pixel } \\
\text { (Terra) } \\
3 \text { pixels (Aqua) } \\
\text { Sept 11: } 3 \text { pixels } \\
\text { (Aqua) }\end{array}$ & $\begin{array}{l}- \\
- \\
1 \text { pixel } \\
2 \text { pixels } \\
-\end{array}$ & Moderate to intense anomalies at or close to summit & $\begin{array}{l}\text { Start of explosive eruptions; lava lake or hot pyroclastic material emplaced within. } \\
\text { Thermal anomalies identified sporadically due to cloud coverage and ash plume } \\
\text { masking the summit. }\end{array}$ \\
\hline
\end{tabular}

MODIS. The data however suggest that no lava flows were emitted along the flanks after the start of the explosive phase. Hot pixels were detected on September 8-11 at the summit, indicating the presence of lava in the crater. Individual thermally anomalous pixels were sporadically detected along the flanks, which could suggest localized bush fires started by material ejected from the crater.

\subsection{Ash plume and burn scars}

The September 4 ASTER data are particularly useful because they represent a snapshot of the initial eruption plume from $\mathrm{OL}-$ the first time an eruption plume potentially containing a mixture of silicate and natrocarbonatite ash has ever been observed with multispectral TIR data. Past silicate eruptions from OL have consisted of rocks such as nephelinite, ijolite (nepheline+augite), and pyroxenite (Oppenheimer, 1998; Klaudius and Keller, 2006). The plume was hypothesized to contain a mixture of Na-carbonate minerals, perhaps hydrated by their exposure to the humid atmosphere (e.g., gaylussite), and silicate minerals that are typical of past explosive eruptions (e.g., nepheline) (Dawson et al., 1968; Dawson et al., 1995; Oppenheimer, 1998; Klaudius and Keller, 2006). Analyses of the TIR data using a decorrelation stretch (DCS) color enhancement (Gillespie et al., 1986), and the spectral emissivity information, were used to examine the composition of different parts of the plume. The plume can be seen in the visible image (Fig. 7d) as the thick white and gray material, and in the TIR temperature image (Fig. 7a) as the dark (cooler) material, emanating from the $\mathrm{OL}$ summit. The plume was mostly blowing to the south at the time of this image, but there was a thinner segment of the plume curving to the northwest, possibly at a different elevation or from a different time.

Laboratory TIR spectra of nepheline and gaylussite resampled to the ASTER spectral response functions are shown in Fig. 7b compared to ASTER emissivity spectra from four different areas. Fig. 7c shows a DCS image using TIR radiance channels 14,13 , and 11 as $R, G$, and $B$. The Na-Ca-sulfate salt deposits around Lake Natron appear yellow 

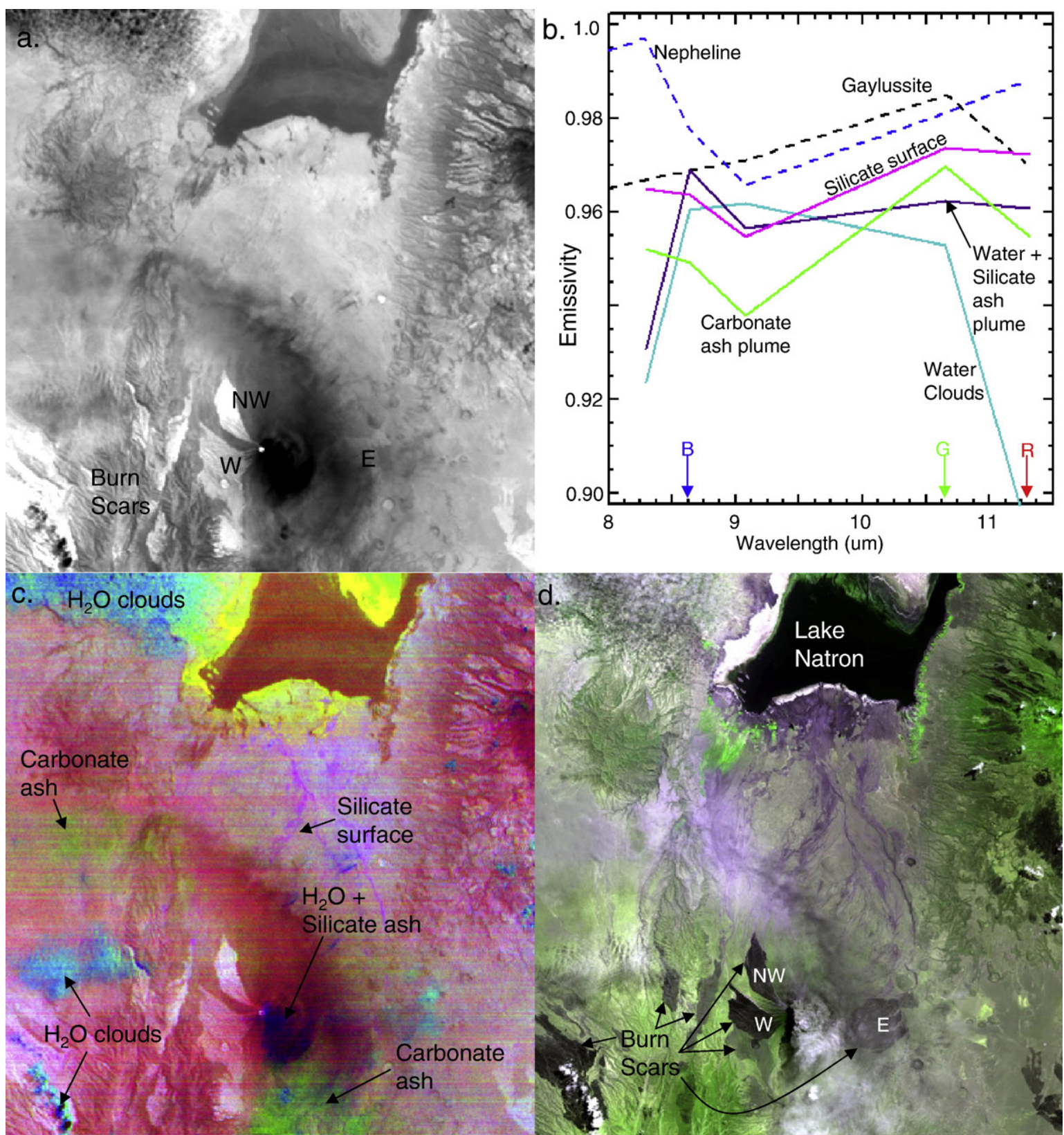

Fig. 7. September 4, 2007 ASTER images of the explosive eruption just about $12 \mathrm{~h}$ after it started. a. ASTER TIR temperature image showing the strong thermal anomaly at the summit, the elevated temperatures of recent burn scars, and the cooler eruption plume drifting to the south and also to the northwest. b. Spectra of nepheline and gaylussite (convolved to ASTER's spectral response functions) and ASTER emissivity spectra of four different regions, labeled in the DCS image. Also shown are the locations of the channels used to drive the RGB colors in the DCS image. c. ASTER DCS image using channels 14-13-11 and R-G-B, enhancing emissivity variations in the scene and showing the plume structure and composition. d. ASTER VNIR image with channels 2-3-1 and R-G-B. The ash plume is gray and steam in the plume is white, vegetation is green, and recently burned areas are dark gray to black.

due to a strong emissivity low around $8.6 \mu \mathrm{m}$ (blue DCS channel); water-rich meteorological clouds appear cyan to blue due to a strong emissivity low beyond $11.2 \mu \mathrm{m}$ (red DCS channel); the land surface appears red to magenta due to the presence of silicate rocks and soils, which result in an emissivity low around $9.0 \mu \mathrm{m}$. Where to plume is thickest (dark purple area just south of the OL summit) the emissivity spectrum indicates that it is dominated by water, but also contains a silicate component causing an emissivity low around $9.0 \mu \mathrm{m}$ and lack of an emissivity low around $11.2 \mu \mathrm{m}$, compared to the spectrum from water clouds (cyan - Fig. 7b). The thinner segments of the plume farther to the south and also to the northwest appear green because the spectra exhibit emissivity lows at $9.0 \mu \mathrm{m}$ (due to a silicate component) and at $11.2 \mu \mathrm{m}$ (due to a carbonate component). However, where the plume is optically thin it is difficult to determine whether the silicate component is radiating from the plume or from the ground beneath. In the case of the green areas, the silicate component may be coming from the ground surface. However based on analysis of previous scenes with no ash plume, there is no significant carbonate material on the surface that could account for the $11.2 \mu \mathrm{m}$ emissivity low that is responsible for the green color in the DCS image. This supports the hypothesis that there are carbonates in the ash plume. Further, it is the presence of silicate emissivity features in the otherwise water-dominated part of the plume that is optically thick that supports the hypothesis that this was a mixed silicate + carbonate eruption. This hypothesis is also supported by recent analyses of ash samples by Mitchell and Dawson (2008).

In Fig. 7d (VNIR image) recent burn scars are evident along the west, northwest and east flanks of the volcano. Older burn scars are 
also located in areas to the south and west that are not adjacent to the volcano - these are from previous bush fires that were not related to volcanic activity. The three burned areas adjacent to OL that were likely caused by recent lava flows down the east, west, and northwest flanks are labeled E, W, and NW, respectively. The E burn scar is mostly obscured by the ash plume and does not appear warmer than the surrounding areas in the TIR temperature image (Fig. 7c). The W and NW burn scars are clearly visible as dark areas in the VNIR image and warmer (brighter) areas in the temperature image. The NW burn scar is warmest with an average temperature of $51^{\circ} \mathrm{C}$. Although no smoke appears to be coming from this area in the image, it is possible for smokeless burning embers to generate residual heat for several days after a fire, depending on the fuel (C. Kolden, personal communication, 2008). The NW burn scar was interpreted to be the most recent because of the higher temperature compared to the other burn scars, likely due to a combination of residual heat and solar heating of newly exposed ground. The West burn scar is interpreted to be the next oldest with an average temperature of $45^{\circ} \mathrm{C}$, due mostly to solar heating of newly exposed ground, and is adjacent to an older burn scar to the south. In the TIR data they appear to be about the same temperature, but in the VNIR image the older scar to the south is clearly more faded, possibly due to vegetation re-growth, similar to the isolated fire scars to the west. This interpretation is consistent with field reports that lava was overflowing the crater on September 1 and igniting fires down the west and northwest flanks that burned until at least September 3 (Belton, 2007).

\section{Summary and conclusions}

During the first few months of 2007 OL exhibited little to no significant activity, with only fumaroles and possibly open vents radiating enough heat to be detected by ASTER, but only during the nighttime. The ASTER scene from June 18 was the first indication that new effusive activity had begun in the summit crater. This was consistent with the first MODIS detection of a thermal anomaly at the summit, June 20 (using the MODLEN algorithm) and also field reports of new activity starting on June 17. The temperatures derived from ASTER TIR radiance data using a 2-component thermal model were consistent with radiative cooling of natrocarbonatite lavas. The relatively high temperature retrieved from the ASTER data on September 4, combined with the spectral interpretation of both carbonate and silicate minerals in the ash plume supported the hypothesis that the new explosive eruption phase was producing more silicate-rich material, which was consistent with past explosive eruptions of OL. Recent analyses of ash samples by Mitchell and Dawson (2008) confirm that the eruptive materials consisted of a mixture of silicate and carbonate minerals.

During mid-July 2007 there had been a swarm of earthquake activity in the region that led to some exaggerated local reports of a new explosive eruption at OL, including an ash plume and lava flows down the flanks of the volcano causing some injuries and forcing local evacuations. Both ASTER and MODIS data revealed that there was thermal activity at OL during this time, but that it was confined to the summit. The discovery of new lava activity at the summit as early as midJune did not support the hypothesis that the June-July eruptive events at OL were triggered by the mid-July swarm of seismic activity detected in the area. However, the change in eruption style from typical effusive natrocarbonatite lava flows in June and July to more voluminous lava flows and an explosive eruption that was coincident with continued large earthquakes in August and September is conspicuous and the possibility of a causal relationship requires further study.

The natrocarbonatite lava eruptions in June and July were typical of previous eruptions over the past several years. The more intense thermal activity detected by both ASTER and MODIS in August and September due to more intense lava flows preceded the explosive eruption on September 4 by about 2 weeks. Given the recurrence interval for explosive eruptions at OL observed during the last century (20-30 years) this type of eruption had been expected as it had been 40 years since the last explosive eruption at OL. Sufficient characterization of background heat flux, typical lava flow events and refined knowledge of the recurrence interval for explosive eruptions will help forecast volcanic activity at OL in the future.

Daily MODIS data combined with field reports were most useful for recording a time-series of the activity. Rapid processing and analysis of MODIS data could also be used to warn people in the area that unusually intense activity was occurring. ASTER data were most useful for providing more detailed information about the specific characteristics of each eruptive event (including surface temperatures and the composition of the ash plume) and were capable of detecting more subtle background thermal anomalies. This highlights the complementary nature of ASTER, MODIS and (if available) field observations, and also demonstrates the value of satellite data for validating the accuracy of local reports of volcanic activity in remote areas. Multiplatform, multispectral satellite data spanning the VNIR through the TIR wavelength regions continue to prove invaluable for monitoring volcanic activity in remote regions.

\section{Acknowledgements}

The research described in this paper was carried out in part at the Jet Propulsion Laboratory, California Institute of Technology, under a contract with NASA as part of the Earth Observing System Mission to Planet Earth Program. Work by RGV was funded by a Caltech postdoctoral fellowship. MK is supported by the Belgian NSF (FWOVlaanderen). Thanks to Mike Ramsey and Joerg Keller for providing very helpful reviews of this manuscript. Thanks to Leon Maldonado for prioritizing ASTER data acquisitions for this eruption. Also, Jurgis Klaudius, Gerald Ernst, Fred Belton, Hannes Mattsson, Rohit Nandedkar, Chris Weber are thanked for providing information and pictures of OL activity and for discussing interpretation of the current eruptive events. Reference herein to any specific commercial product, process, or service by trade names, trademark, manufacturer or otherwise does not imply endorsement by the United States or the Jet Propulsion Laboratory, California Institute of Technology.

\section{References}

Abtahi, A.A., Kahle, A.B., Abbot, E.A., Gillespie, A.R., Sabol, D., Yamada, G., Pieri, D.C., 2002. Emissivity changes in basalt cooling after eruption from Pu'u O'o. Eos Transactions, American Geophysical Union 83, V71A-V1263A Abstract.

Belton, F., 2007. http://www.mtsu.edu/ fbelton/lengai.html.

Belton, F., 2007. http://www.mtsu.edu/ fbelton/lengai.html.
Byrnes, J.M., Ramsey, M.S., Crown, D.A., 2004. Surface unit characterization of the Mauna Ulu flow field, Kilauea Volcano, Hawaii, using integrated field and remote sensing analyses. Journal of Volcanology and Geothermal Research 135, 169-193.

Crisp, J., Baloga, S., 1990. A model for lava flows with two thermal components. Journal of Geophysical Research 95 (B2), 1255-1270.

Dawson, J.B., 1992. Neogene tectonics and volcanicity in the North Tanzania sector of the Gregory Rift Valley: contrasts with the Kenya sector. Tectonophysics 204, 81-92.

Dawson, J.B., Bowden, P., Clark, G.C., 1968. Activity of the carbonatite volcano Oldoinyo Lengai, 1966. Geologische Rundschau 57, 865-879.

Dawson, J.B., Garson, M.S., Roberts, B., 1987. Altered former alkalic carbonatite lava from Oldoinyo Lengai, Tanzania: inferences for calcite carbonatite lavas. Geology 15, 765-768.

Dawson, J.B., Pinkerton, H., Norton, G.E., Pyle, D.M., 1990. Physicochemical properties of alkali carbonatite lavas: data from the 1988 eruption of Oldoinyo Lengai, Tanzania. Geology 18, 260-263.

Dawson, J.B., Pinkerton, H., Pyle, D.M., Nyamweru, C., 1994. June 1993 eruption of Oldoinyo Lengai, Tanzania: exceptionally viscous and large carbonatite lava flows and evidence for coexisting silicate and carbonate magmas. Geology 22, 799-802.

Dawson, J.B., Keller, J., Nyamweru, C., 1995. Historic and recent eruptive activity of Oldoinyo Lengai. In: Bell, K., Keller, J. (Eds.), Carbonatite Volcanism: Oldoinyo Lengai and the Petrogenesis of Natrocarbonatites. IAVCEI Proceedings in Volcanology, vol. 4. SpringerVerlag, pp. 4-22.

Dozier, J., 1981. A method for the satellite identification of surface temperature fields of subpixel resolution. Remote Sensing of Environment 11, 221-229.

Flynn, L.P., Wright, R., Garbeil, H., Harris, A.J.L., Pilger, E., 2002. A global thermal alert system using MODIS: initial results from 2000-2001. Advances in Environmental Monitoring and Modelling 1, 37-69. 
Gillespie, A.R., Kahle, A.B., Walker, R.E., 1986. Color enhancement of highly correlated images. I. Decorrelation and HIS contrast stretches. Remote Sensing of Environment 20, 209-235.

Gillespie, A.R., Rokugawa, S., Matsunaga, T., Cothern, J.S., Hook, S.J., Kahle, A.B., 1998. A Temperature and emissivity separation algorithm for Advanced Spaceborne Thermal Emission and Reflection Radiometer (ASTER) images. IEEE Transactions on Geoscience and Remote Sensing 36 (4), 1113-1126.

GVN, 2000. Oldoinyo Lengai: continued intermittent eruptive activity, scientist burned by lava. Bulletin of the Global Volcanism Network 25 (12).

GVN, 2002. Oldoinyo Lengai: lava exits crater at 3 points during January 2001September 2002. Bulletin of the Global Volcanism Network 27 (10).

GVN, 2003. Oldoinyo Lengai: continuing lava flows and vent activity in late December 2002. Bulletin of the Global Volcanism Network 28 (02).

GVN, 2004. Oldoinyo Lengai: during February 2004, lavas still escape crater; temperature measurements. Bulletin of the Global Volcanism Network 29 (02)

GVN, 2005. Oldoinyo Lengai: tall hornito almost reaches summit elevations; more lava spills over rim. Bulletin of the Global Volcanism Network 30 (04).

Harris, A.J.L., Flynn, L.P., Rothery, D.A., Oppenheimer, C., Sherman, S.B., 1999. Mass flux measurements at lava lakes: implications for magma recycling. Journal of Geophysical Research 104, 7117-7136.

Keller, J., Krafft, M., 1990. Effusive natrocarbonatite activity, Oldoinyo Lengai, June 1988 Bulletin of Volcanology 52, 629-645.

Kervyn, M., Harris, A.J.L., Belton, F., Mbede, E., Jacobs, P., Ernst, G.G.J., 2006. MODLEN: A semi-automated algorithm for monitoring small-scale thermal activity at Oldoinyo Lengai Volcano, Tanzania, Int. Assoc. for Mathematical Geology. XIth International Congress. Université de Liège, Belgium.

Kervyn, M., Harris, A.J.L., Belton, F., Mbede, E., Jacobs, P., Ernst, G.G.J., in press-a. Therma remote sensing of the low-intensity carbonatite volcanism of Oldoinyo Lengai, Tanzania, International Journal of Remote Sensing.

Kervyn, M., Ernst, G.G.J., Klaudius, J., Keller, J., Kervyn, F., Mattsson, H.B., Belton, F. Mbede, E., Jacobs, P., in press-b. Voluminous lava flows at Oldoinyo Lengai in 2006: chronology of events and insights into the shallow magmatic system. Bull. Volcanol. doi:10.1007/s00445-00007-00190-x.

Klaudius, J., Keller, J., 2004. Quaternary debris avalanche deposits at Oldoinyo Lengai (Tanzania). IAVCEI General Assembly Abstracts with Program, Pucon, Chili.

Klaudius, J., Keller, J., 2006. Peralkaline silicate lavas at Oldoinyo Lengai, Tanzania. Lithos 91, 173-190.

Koberski, U., Keller, J., 1995. Cathodoluminescence observations in natro-carbonatites and related peralkaline nephelinites at Oldoinyo Lengai. In: Bell, K., Keller, J. (Eds.), Carbonatite Volcanism: Oldoinyo Lengai and the Petrogenesis of Natrocarbonatites. IAVCEI Proceedings in Volcanology, pp. 87-99.

Krafft, M., Keller, J., 1989. Temperature measurements in carbonatite lava lake and flows: Oldoinyo Lengai, Tanzania. Science 245, 168-170.

Lombardo, V., Buongiorno, M.F., 2003. Temperature distribution analysis of July 2001 Mt. Etna eruption observed by the airborne hyperspectral sensor MIVIS. Annals of Geophysics 46 (6).

Lombardo, V., Buongiorno, M.F., Pieri, D., Merucci, L., 2004. Differences in Landsat TM derived lava flow thermal structures during summit and flank eruption at Mount Etna. Journal of Volcanology and Geothermal Research 134, 15-34.

Mitchell, R.H., Dawson, J.B., 2008. The September 24th, 2007 ash eruption of the carbonatite volcano, Oldoinyo Lengai, Tanzania: mineralogy of the ash and implications for formation of new hybrid magma type. Mineralogical Magazine, In Review.

Norton, G.E., Pinkerton, H., 1997. Rheological properties of natrocarbonatite lavas from Oldoinyo Lengai, Tanzania. European Journal of Mineralogy 9, 351-364.
Nyamweru, C., 1990. Observations on changes in the active crater of Oldoinyo Lengai from 1960 to 1988. Journal of African Earth Sciences 11, 385-390.

Nyamweru, C., 1997. Changes in the crater of Oldoinyo Lengai: June 1993 to February 1997. Journal of African Earth Sciences 25, 43-53.

Oppenheimer, C., Francis, P.W., Rothery, D.A., Carlton, R.W.T., 1993. Infrared image analysis of volcanic thermal features: Lascar volcano, Chile 1984-1992. Journal of Geophysical Research 98, 4269-4286.

Oppenheimer, C., 1998. Satellite observation of active carbonatite volcanism at Ol Doinyo Lengai, Tanzania. International Journal of Remote Sensing 19 (1), 55-64.

Oyen, A., d'Oreye, N., Kervyn, F., Kervyn, M., 2007. InSAR monitoring of Ol Doinyo Lengai (Tanzania): the March 2006 and July 2007 events. Active volcanism and continental rifting. 26th ECGS Workshop, Luxembourg, November 19-21, 2007.

Pieri, D.C., Glaze, L.S., Abrams, M.J., 1990. Thermal radiance observations of an active lava flow during the 1984 eruption of Mount Etna. Geology 18, 1023-1027.

Pieri, D.C., Abrams, M.J., 2005. ASTER observations of thermal anomalies preceding the April 2003 eruption of Chikurachki Volcano, Kurile Islands, Russia. Remote Sensing of Environment 99, 84-94.

Pinkerton, H., Norton, G.E., Dawson, J.B., Pyle, D.M., 1995. Field observations and measurements of the physical properties of Oldoinyo Lengai alkalic carbonatite lavas, November 1988. In: Bell, K. Keller J. (Eds.), Carbonatite Volcanism: Oldoinyo Lengai and the Petrogenesis of Natrocarbonatites. IAVCEI Proceedings in Volcanology, vol. 4. Springer-Verlag, pp. 23-36.

Rothery, D.A., Francis, P.W., Wood, C.A., 1988. Volcano monitoring using short wavelength infrared data from satellites. Journal of Geophysical Research 93 (B7), 7993-8008.

Salomonson, V., Barnes, W., Maymon, P., Montgomery, H., Ostrow, H., 1989. MODIS: advanced facility instrument for studies of the Earth as a system. IEEE Transactions on Geoscience and Remote Sensing 27 (4), 145-153.

Thome, K., Palluconi, F., Takashima, T., Masuda, K., 1998. Atmospheric correction of ASTER. IEEE TGARS 36 (4), 1199-1211.

Tonooka, H., Iwasaki, A., 2003. Improvement of ASTER/SWIR crosstalk correction. Proc. SPIE, vol. 5234, pp. 168-179.

Wolff, J.A., 1994. Physical properties of carbonatite magmas inferred from molten salt data, and application to extraction patterns from carbonatite silicate magma chambers. Geological Magazine 131, 145-153.

Wooster, M.J., Rothery, D.A., 1997. Thermal monitoring of Lascar Volcano, Chile using infrared data from the Along Track Scanning Radiometer: a 1992-1995 time-series. Bulletin of Volcanology 58, 566-579.

Wright, R., Rothery, D.A., Blake, S., Harris, A.J.L., Pieri, D.C., 1999. Simulating the response of the EOS Terra ASTER sensor to high-temperature volcanic targets. Geophysical Research Letters 26 (12), 1773-1776.

Wright, R., Rothery, D.A., Blake, S., Pieri, D.C., 2000. Improved remote sensing estimates of lava flow cooling: a case study of the 1991 to 1993 Mount Etna eruption. Journal of Geophysical Research (Solid Earth) 105, 23681-23694.

Wright, R., Flynn, L.P., 2003. On the retrieval of lava flow surface temperatures from infrared satellite data. Geology 31, 893-896.

Wright, R., Flynn, L.P., Garbeil, H., Harris, A.J.L., Pilger, E., 2004. MODVOLC: near-realtime thermal monitoring of global volcanism. Journal of Volcanology and Geothermal Research 135, 29-49.

Yamaguchi, Y., Kahle, A.B., Tsu, H., Kawakami, T., Pniel, M., 1998. Overview of Advanced Spaceborne Thermal Emission and Reflection Radiometer (ASTER). IEEE Transactions on Geoscience and Remote Sensing 36 (4), 1062-1071.

Zaitsev, A.N., Keller, J., 2006. Mineralogical and chemical transformation of Oldoinyo Lengai natrocarbonatites, Tanzania. Lithos 91, 191-207. 